\title{
Therapeutic Use of Extracellular Vesicles for Acute and Chronic Lung Disease
}

\author{
Erin N. Worthington and James S. Hagood * \\ Division of Pulmonology, Department of Pediatrics, University of North Carolina at Chapel Hill, Chapel Hill, \\ NC 27599, USA; nikki@unc.edu \\ * Correspondence: jhagood@unc.edu; Tel.: +01-919-966-1055
}

Received: 24 February 2020; Accepted: 25 March 2020; Published: 27 March 2020

\begin{abstract}
Multipotent mesenchymal stem cells (MSCs) possess regenerative properties and have been shown to improve outcomes and survival in acute and chronic lung diseases, but there have been some safety concerns raised related to MSC-based therapy. Subsequent studies have demonstrated that many of the regenerative effects of MSCs can be attributed to the MSC-derived secretome, which contains soluble factors and extracellular vesicles (EVs). MSC-derived extracellular vesicles (MSC-derived EVs) replicate many of the beneficial effects of MSCs and contain a variety of bioactive factors that are transferred to recipient cells, mediating downstream signaling. MSC-derived EV therapy holds promise as a safe and effective treatment for pulmonary disease, but there remain many scientific and clinical questions that will need to be addressed before EVs are widely applied as a therapy. To date, the use of MSC-derived EVs as a treatment for lung disease has been conducted primarily in in vitro or pre-clinical animal models. In this review, we will discuss the current published research investigating the use of EVs as a potential therapeutic for acute lung injury/acute respiratory distress syndrome (ALI/ARDS), bronchopulmonary dysplasia (BPD), idiopathic pulmonary fibrosis (IPF), pulmonary arterial hypertension (PAH), asthma, and silicosis.
\end{abstract}

Keywords: extracellular vesicles; lung disease; mesenchymal stem cells; pulmonary disease

\section{Introduction}

Stem cell research has garnered significant attention over the last few decades, especially regarding potential applications for the regeneration of damaged or diseased tissue [1]. Stem cells are self-renewing and undifferentiated cell types that are classified by their potential to differentiate into functional cells and further described as totipotent, pluripotent, multipotent, and unipotent [1-3]. Multipotent stem cells are able to differentiate into cell types of a particular cellular lineage. Mesenchymal stem cells (MSCs) are multipotent cells found in multiple anatomic compartments (e.g., bone marrow, adipose tissue, umbilical cord, and lungs) which, in addition to serving as progenitors for connective tissue cells, are able to stimulate the growth, repair, and survival of other cells and tissues [4]. MSCs have been shown to have a beneficial immunomodulatory and regenerative capacity. There is a significant body of research published describing MSCs as a potential therapy for several acute and chronic lung diseases, summarized in recently published comprehensive reviews $[3,5,6]$. While many experimental and clinical studies have established the use of MSCs in lung disease, there have been some safety concerns raised related to MSC-based therapy, which include the undesirable differentiation of transplanted MSCs resulting in possible malignant transformation, as well as vascular occlusion caused by injected MSCs [7]. More recent studies have discovered that the MSC secretome contains soluble factors and extracellular vesicles (EVs), which can mimic many of the desired clinical effects of MSCs [8]. EVs are hypothesized to be a safer alternative to MSCs since they are cell free and appear to have a better immunogenicity, tumorigenicity, and embolism formation side effect profile than MSCs $[9,10]$. This 
has led to increased efforts to develop MSC-derived extracellular vesicles (MSC-derived EVs) as a potential therapeutic agent.

\section{Extracellular Vesicles}

EVs are naturally occurring, cell-derived membrane-bound spherical structures that are shed or secreted from most cell types under various physiologic and pathologic conditions into the circulation or surrounding body fluids. EVs have been found in a variety of biological fluids, including blood, bile, bronchoalveolar lavage fluid (BALF), and urine [11]. EVs are important for cell-to-cell communication as they provide a way for cells to exchange cellular components, which can influence a broad range of signaling pathways [12].

EVs range between 30-5000 $\mathrm{nm}$ in diameter, and until recently have been classified based on size, which included exosomes (30-100 nm), microvesicles/ectosomes (100-1000 nm), and apoptotic bodies (100-5000 nm). These categories of EVs also have distinct mechanisms of release from cells, as described below. The International Society for Extracellular Vesicles (ISEV) now recommends using "extracellular vesicle" as an umbrella term to describe vesicles of all sizes, due to the size heterogeneity and lack of specific markers for each EV size classification [13]. The most recent ISEV guidelines recommend EVs be described by physical characteristics, biochemical composition, or descriptions of conditions or cells of origin in place of the former size-based terms [13]. Furthermore, additional guidelines in this position statement describe the minimal experimental requirements needed when performing experiments with EVs [13].

The formation of EVs include three distinct biogenetic pathways. First, exosome biogenesis is dependent on the endosomal sorting complexes required for transport (ESCRT) protein for the formation of endosomal intraluminal vesicles resulting in multivesicular bodies (MVBs), from which exosomes are released via exocytosis when MVBs fuse with the plasma membrane [14,15]. This pathway has been exploited by viruses for viral egress from an infected cell [16]. Second, microvesicles are shed via the outward blebbing of the plasma membrane and then released via proteolytic cleavage [14]. Third, apoptotic bodies are formed by membrane blebbing during apoptotic cell disassembly.

EVs express cell surface proteins similar to the cells from which they are derived and contain various cytoplasmic components, including proteins, RNA (including mRNA and noncoding RNA such as microRNA (miRNA)), lipids, mitochondria, and DNA [12]. The contents of EVs reflect their modes of biogenesis, cellular origin, physiological or culture conditions, and exogenous stimuli. It has been shown that exposure of MSCs to hypoxia or growth factors increased EV production and altered EV cargo, resulting in enhanced effects [17-19]. The determinants of EV contents are not well understood and may include both passive and regulated mechanisms. Overall, the individual function of an EV depends not just on its contents but also on the expression of biomarkers on its plasma surface. Plasma-membrane-derived EVs may contain putative markers: TyA, C1q, Arrestin domain-containing protein 1 (ARRDC1), and CD73. Endosome-derived EVs may express distinct biomarkers, including tetraspanins (CD61, CD63, CD81), ESCRT proteins (TSG101 and Alix), syntenin, flotillin, and heat shock proteins. These biomarkers may suggest a biogenetic lineage but are not always specific as there can be some cross-over among these.

The cellular targeting, uptake, and plasma membrane fusion of EVs is another area of ongoing investigation that is proving to be complex and multifaceted $[12,15,20,21]$. The interaction of EVs with recipient cells involves numerous molecular interactions that affect various downstream signaling events and can include signaling through membrane proteins, binding to cell surface receptors, and/or the delivery of the EV cargo (e.g., Protein, DNA, RNA, miRNA, and lipids) to various intracellular compartments via EV uptake via either cell membrane fusion or endocytosis. Thus, EVs are able to mediate intracellular communication via shuttling bioactive signaling molecules as cargo or by the direct activation of signaling pathways to a recipient cell. 


\section{MSC-Derived EVs in Models of Lung Disease}

The use of MSC-derived EVs as a potential therapy for lung disease is a fairly young but rapidly growing field, with current research covering a wide variety of lung diseases (Figure 1) [22]. The majority of the current research evaluating the therapeutic potential of EVs has been performed in in vitro or pre-clinical animal model systems (Table 1). This review will describe current published research using EVs as a potential therapy for acute lung injury/acute respiratory distress syndrome (ALI/ARDS), bronchopulmonary dysplasia (BPD), idiopathic pulmonary fibrosis (IPF), pulmonary arterial hypertension (PAH), asthma, and silicosis.

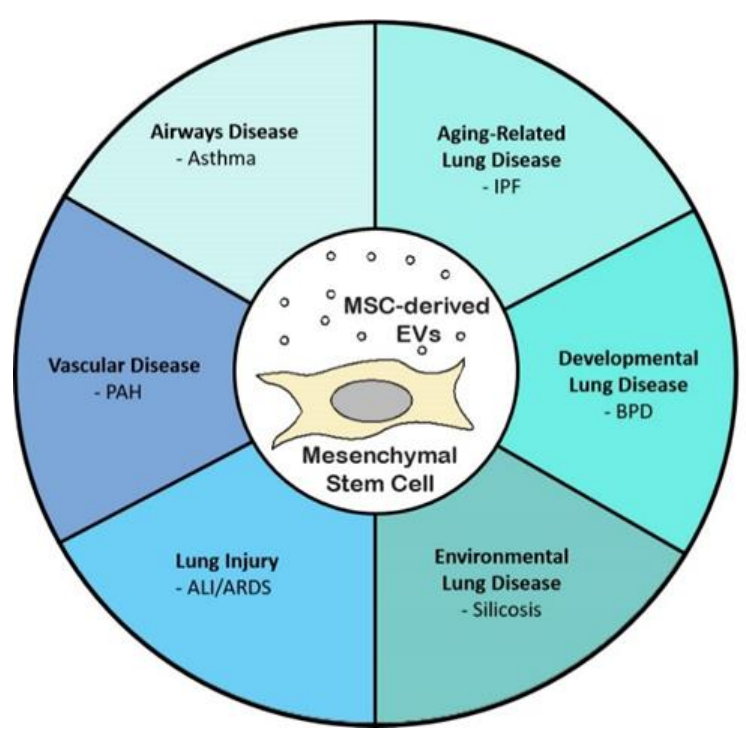

Figure 1. Multipotent mesenchymal stem cell-derived extracellular vesicles (MSC-derived EVs) as a potential therapeutic for lung diseases. The in vitro and pre-clinical studies evaluating the potential therapeutic role of MSC-derived EVs have shown promising results. in many different categories of lung diseases.

\subsection{Acute Lung Injury/Acute Respiratory Distress Syndrome}

Acute lung injury and acute respiratory distress syndrome (ALI/ARDS) is a disease that carries a high burden of morbidity and mortality [23-25]. It is characterized by rapid onset respiratory failure resulting from various direct and indirect insults to the lung parenchyma or vasculature. The pathophysiology includes a severe inflammatory response and high levels of circulating cytokines resulting in ongoing damage to lung tissue. Treatment with anti-inflammatories has been ineffective at reducing mortality rates or improving outcomes in patients with ALI/ARDS [26]. Several ALI/ARDS model systems have shown treatment with MSC-derived EVs resulted in a reduction in lung injury severity.

MSC-derived EVs have demonstrated beneficial effects in both bacterial- and viral-induced ALI. In an influenza-induced ALI porcine model, intratracheal (IT) treatment with swine bone marrow MSC-derived EVs $12 \mathrm{~h}$ after influenza virus infection resulted in reduced viral replication, viral shedding, and reduced production of pro-inflammatory cytokines [27]. In an Escherichia coli pneumonia murine model, Monsel and colleagues demonstrated that the intravenous (IV) administration of human bone marrow MSC-derived EVs improved survival and reduced inflammation [28]. This study also shows that MSC-derived EVs were effective in vitro via increased human macrophage bacterial phagocytosis, reduced inflammation, and increased ATP levels in human alveolar type 2 cells. Another study showed human bone marrow MSC-derived EVs protected against ALI by promoting an anti-inflammatory and a highly phagocytic macrophage phenotype, and demonstrating a role for EV-mediated mitochondrial transfer in this observed effect [29]. 
A variety of studies have used an endotoxin-mediated in vivo model to evaluate the effects of MSC-derived EVs for ALI/ARDS. For instance, the IT instillation of human bone marrow MSC-derived EVs in a murine E. coli endotoxin-induced ALI model resulted in improvements in pulmonary edema and lung protein permeability due to reduced extravascular lung water and total protein in BALF [30]. Additionally, MSC-derived EV-treated ALI mice demonstrated a reduction in neutrophil infiltration and macrophage inflammatory protein-2 (MIP-2) levels in the alveoli, suggesting anti-inflammatory effects [30]. Furthermore, this study suggests a possible role of keratinocyte growth factor mRNA transfer and subsequent protein expression to the injured alveolar epithelium [30]. Tang and colleagues demonstrated that the IT instillation of human bone marrow MSC-derived EVs in a murine lipopolysaccharide (LPS)-induced ALI model resulted in reduced inflammation by a reduction in the influx of white blood cells, neutrophils, and MIP-2 secretion [31]. In addition, the MSC-derived EVs contained angiopoietin-1 (Ang-1) mRNA, and Ang-1 protein expression in alveolar cells was increased in the EV treated mice. The knockdown of Ang-1 in the MSC parent cells partially ameliorated the beneficial effects of the MSC-derived EVs, suggesting that the transfer of Ang-1 mRNA by EVs is important for the protective effects in this system. This study also showed that EVs suppressed the secretion of TNF-alpha and inflammatory cytokines, while increasing the secretion of an anti-inflammatory cytokine, interleukin-10 (IL-10), in a mouse macrophage cell line. Another study showed that MSC-derived EVs restored partial protein permeability across injured human lung microvascular endothelial cells by increasing the transfer of Ang-1 mRNA to the injured endothelium, with resulting increased expression and secretion by injured human lung microvascular endothelial cells [32]. This is significant because Ang-1 is an angiogenic factor that is involved in endothelial cell stabilization during injury, reducing leukocyte-endothelium interactions, and endothelium permeability. Wang and colleagues showed that MSC-derived EVs were able to stabilize the endothelial barrier function of pulmonary microvascular endothelial cells in vitro after treatment with LPS; the knockdown of hepatocyte growth factor inhibited this effect, suggesting that hepatocyte growth factor may have a role in the regulation of endothelial permeability by MSC-derived EVs [33]. Gennai et al. found that MSC-derived EVs increased alveolar fluid clearance in human donor lungs in an ex vivo ischemia/reperfusion-induced ALI model and the expression of CD44 on the MSC-derived EVs was necessary for EV uptake by the recipient cell and downstream effects [34].

\subsection{Bronchopulmonary Dysplasia}

Bronchopulmonary dysplasia (BPD), a leading cause of morbidity and mortality in premature infants, is a chronic lung disease that is multifactorial in origin [35]. The lungs of infants with BPD are underdeveloped due to the arrest or delay of alveolar development and pulmonary angiogenesis. These patients are at increased risk of pulmonary infection, inflammation, and injury throughout infancy and childhood. There is a significant body of research evaluating the utility of using MSCs as a possible therapy for BPD, as highlighted in several recent reviews [35-37]. However, given the success of MSC-derived EVs in other pulmonary diseases, there are now multiple studies looking at the role of MSC-derived EV as therapy for BPD. Willis and colleagues found that umbilical cord MSC-derived EVs improved lung function, decreased both fibrosis and pulmonary vascular remodeling, and resulted in an improvement in pulmonary hypertension in a neonatal murine hypoxia model [38]. EV treatment decreased hyperoxia-induced inflammation and altered the hyperoxic lung transcriptome. The EVs were taken up by alveolar macrophages and suppressed the macrophage M1-like inflammatory state and increased the M2-like anti-inflammatory state both in vitro and in vivo. Chaubey et al. demonstrated in a neonatal murine BPD model that umbilical cord MSC-derived EVs reduced pulmonary inflammation, pulmonary hypertension, and right ventricular hypertension partially mediated through the exosomal protein tumor necrosis factor alpha-stimulated gene-6 (TSG-6) [39]. In another report, umbilical cord MSC-derived EVs were as effective as the parental MSCs in protecting against hypoxia-induced lung injury in neonatal rats [40]. These beneficial effects were partially attenuated by knocking down the vascular endothelial growth factor (VEGF) gene in MSCs prior to EV isolation. 
Table 1. EV treatment in preclinical models of lung disease.

\begin{tabular}{|c|c|c|c|c|c|c|c|c|c|}
\hline & \multirow{2}{*}{ EV Origin } & \multicolumn{2}{|c|}{ Model System } & \multicolumn{3}{|c|}{ EV } & \multirow[b]{2}{*}{ Outcomes } & \multirow{2}{*}{ Key Modulator } & \multirow[b]{2}{*}{ Ref. } \\
\hline & & Species & Injury & Route & Dose & $\begin{array}{l}\text { Isolation } \\
\text { Method }\end{array}$ & & & \\
\hline \multirow[t]{5}{*}{ ALI/ARDS } & $\begin{array}{c}\text { Swine } \\
\text { BM-MSCs }\end{array}$ & pig & Influenza & IT & $\begin{array}{l}\text { EVs released by } 10 \times \\
10^{6} \text { MSCs over } 48 \mathrm{~h}\end{array}$ & $\mathrm{UCF}$ & $\begin{array}{l}-\downarrow \downarrow \text { Virus replication and shedding and } \\
\text { inflammatory cytokines }\end{array}$ & $\begin{array}{l}\text { EV RNA transfer to } \\
\text { epithelial cells }\end{array}$ & [27] \\
\hline & $\begin{array}{l}\text { Human } \\
\text { BM-MSCs }\end{array}$ & mouse & $\begin{array}{c}\text { E. coli } \\
\text { pneumonia }\end{array}$ & IT/IV & $\begin{array}{l}\text { EVs released by } 3-6 \times \\
10^{6} \text { MSCs (IT) or } 9 \times \\
10^{6} \text { MSCs (IV) over } 48 \mathrm{~h} \\
\end{array}$ & UCF & $\begin{array}{l}\text { - } \uparrow \text { Survival } \\
\bullet \quad \downarrow \text { Influx of inflammatory cells, } \\
\text { cytokines, and bacterial load }\end{array}$ & EV transfer of KGF mRNA & [28] \\
\hline & $\begin{array}{l}\text { Human } \\
\text { BM-MSCs }\end{array}$ & mouse & LPS & Ex vivo & $\begin{array}{l}\text { EVs released by } 1.5 \times \\
10^{7} \text { MSCs over } 48 \mathrm{~h}\end{array}$ & $\mathrm{UCF}$ & $\begin{array}{l}\text { - } \quad \downarrow \text { Lung inflammation and injury } \\
\text { - Promoted anti-inflammatory and } \\
\text { phagocytic macrophage phenotype }\end{array}$ & $\begin{array}{l}\text { EV-mediated mitochondrial } \\
\text { transfer }\end{array}$ & [29] \\
\hline & $\begin{array}{l}\text { Human } \\
\text { BM-MSCs }\end{array}$ & mouse & $\begin{array}{l}\text { E. coli } \\
\text { endotoxin }\end{array}$ & IT/IV & $\begin{array}{l}\text { EVs released by } 3 \times 10^{6} \\
\text { MSCs over } 48 \mathrm{~h}\end{array}$ & UCF & $\begin{array}{l}\text { - } \downarrow \text { Pulmonary edema, lung protein } \\
\text { permeability, influx of neutrophils, and } \\
\text { MIP-2 expression }\end{array}$ & KGF-expressing EV transfer & [30] \\
\hline & $\begin{array}{l}\text { Human } \\
\text { BM-MSCs }\end{array}$ & mouse & LPS & IT & $\begin{array}{l}\text { EVs released by } 3 \times 10^{6} \\
\text { MSCs over } 48 \mathrm{~h}\end{array}$ & UCF & $\begin{array}{l}\text { - } \quad \downarrow \text { Lung inflammation, influx of } \\
\text { neutrophils, and MIP-2 secretion } \\
\text { - Restored the pulmonary capillary } \\
\text { permeability }\end{array}$ & EV transfer of Ang-1 mRNA & [31] \\
\hline \multirow[t]{3}{*}{ BPD } & $\begin{array}{l}\text { Human } \\
\text { UC-MSCs and } \\
\text { BM-MSCs }\end{array}$ & mouse & Hyperoxia-newborn & IV & $\begin{array}{l}\text { EVs released by } 0.5 \times \\
10^{6} \text { MSCs over } 48 \mathrm{~h}\end{array}$ & $\begin{array}{c}\text { UCF } \\
\text { (Optiprep) }\end{array}$ & $\begin{array}{l}\text { - } \downarrow \text { PAH, alveolar simplification, lung } \\
\text { fibrosis, and vascular remodeling } \\
\text { • Improved PFTs } \\
\text { - } \uparrow \text { Anti-inflammatory macrophage } \\
\text { phenotype }\end{array}$ & $\begin{array}{l}\text { EV mediated macrophage } \\
\text { modulation }\end{array}$ & [38] \\
\hline & $\begin{array}{l}\text { Human } \\
\text { UC-MSCs }\end{array}$ & mouse & Hyperoxia-newborn & IP & $2.5 \mu \mathrm{g}$ protein & $\mathrm{UCF}$ & $\begin{array}{l}\bullet \quad \downarrow \text { Lung inflammation, alveolar } \\
\text { simplification, PAH, and RVH } \\
\bullet \quad \downarrow \text { Cell death in brain and } \\
\text { hypo-myelination }\end{array}$ & $\begin{array}{l}\text { Effects partially modulated } \\
\text { via TSG-6 }\end{array}$ & [39] \\
\hline & $\begin{array}{l}\text { Human } \\
\text { UC-MSCs }\end{array}$ & rat & HIE newborn & IT & $6 \times 10^{9} \mathrm{EVs}$ & $\begin{array}{c}\text { Tangential } \\
\text { flow filtration }\end{array}$ & $\begin{array}{l}\text { - } \downarrow \text { Thickness of small pulmonary } \\
\text { vessels and alveolar simplification }\end{array}$ & & [40] \\
\hline \multirow[t]{3}{*}{ IPF } & $\begin{array}{l}\text { Human } \\
\text { BM-MSCs }\end{array}$ & mouse & $\begin{array}{l}\text { Bleomycin } \\
\text { lung fibrosis }\end{array}$ & IV & $\begin{array}{l}\text { EVs released by } 5 \times 10^{6} \\
\text { MSCs over } 48 \mathrm{~h}\end{array}$ & $\begin{array}{c}\text { UCF } \\
\text { (Optiprep) }\end{array}$ & $\begin{array}{l}-\downarrow \downarrow \text { Lung fibrosis, lung inflammation, } \\
\text { and inflammatory phenotype of } \\
\text { monocytes and macrophages }\end{array}$ & & [41] \\
\hline & $\begin{array}{c}\text { Human } \\
\text { amnion } \\
\text { epithelial cells }\end{array}$ & mouse & $\begin{array}{l}\text { Bleomycin } \\
\text { lung fibrosis }\end{array}$ & $\mathrm{IV} / \mathrm{IN}$ & $10 \mu \mathrm{g}$ protein & $\mathrm{UCF}$ & $\begin{array}{l}\text { - } \quad \downarrow \text { Lung fibrosis and inflammation } \\
\text { suppressed T cell progociferation }\end{array}$ & & [42] \\
\hline & $\begin{array}{l}\text { Human BM- } \\
\text { MSCs }\end{array}$ & mouse & $\begin{array}{l}\text { Bleomycin } \\
\text { lung fibrosis }\end{array}$ & IV & $50 \mu \mathrm{g}$ protein & $\mathrm{UCF}$ & - $\downarrow$ Lung fibrosis & $\begin{array}{l}\text { Thy-1 EV expression } \\
\text { causes } \uparrow \text { EV effects }\end{array}$ & [43] \\
\hline
\end{tabular}


Table 1. Cont

\begin{tabular}{|c|c|c|c|c|c|c|c|c|c|}
\hline & \multirow{2}{*}{ EV Origin } & \multicolumn{2}{|c|}{ Model System } & \multicolumn{3}{|c|}{ EV } & \multirow[b]{2}{*}{ Outcomes } & \multirow{2}{*}{ Key Modulator } & \multirow[b]{2}{*}{ Ref. } \\
\hline & & Species & Injury & Route & Dose & $\begin{array}{l}\text { Isolation } \\
\text { Method }\end{array}$ & & & \\
\hline \multirow[t]{4}{*}{ РAH } & $\begin{array}{l}\text { Mouse } \\
\text { BM-MSCs and } \\
\text { Human } \\
\text { UC-MSCs }\end{array}$ & mouse & Hypoxic PAH & IV & $10 \mu \mathrm{g}$ protein & $\mathrm{UCF}$ & $\begin{array}{l}\bullet \quad \downarrow \text { Lung inflammation and } \\
\text { pulmonary influx of macrophages }\end{array}$ & $\begin{array}{l}\text { Inhibition of STAT3 } \\
\text { signaling and } \uparrow \text { of EV } \\
\text { miR-17 superfamily of } \\
\text { microRNA }\end{array}$ & [44] \\
\hline & Rat BM-MSCs & rat & МСТ РАН & IV & $30 \mu \mathrm{g}$ protein & $\mathrm{UCF}$ & $\begin{array}{l}\text { - } \downarrow \text { PAH, mean PA pressure, mean RV } \\
\text { pressure, and RVH }\end{array}$ & & [45] \\
\hline & $\begin{array}{l}\text { Murine and } \\
\text { Human } \\
\text { BM-MSCs }\end{array}$ & mouse & МСТ РАН & IV & $25 \mu \mathrm{g}$ protein & $\mathrm{UCF}$ & $\begin{array}{l}\bullet \quad \downarrow P A H \text {, and RVH and vascular } \\
\text { remodeling }\end{array}$ & $\begin{array}{l}\uparrow E V \text { miRNAs that } \uparrow \\
\text { anti-proliferative, apoptotic, } \\
\text { or senescent effects }\end{array}$ & [46] \\
\hline & $\begin{array}{l}\text { Human } \\
\text { BM-MSCs }\end{array}$ & rat & $\begin{array}{l}\text { Sugen/hypoxia } \\
\text { PAH }\end{array}$ & IV & $100 \mu \mathrm{g}$ protein $/ \mathrm{kg}$ & $\mathrm{UCF}$ & $\begin{array}{l}\bullet \quad \downarrow R V \text { pressure, } R V H \text {, muscularization } \\
\text { of peripheral pulmonary vessels, and } \\
\text { lung macrophages }\end{array}$ & & [47] \\
\hline \multirow[t]{2}{*}{ Asthma } & $\begin{array}{l}\text { Mouse and } \\
\text { Human } \\
\text { BM-MSCs }\end{array}$ & mouse & $\begin{array}{l}\text { Aspergillus } \\
\text { extract } \\
\text { hyphae }\end{array}$ & IV & $\begin{array}{l}\text { EVs released by } 3 \times 10^{6} \\
\text { MSCs over } 48 \mathrm{~h}\end{array}$ & $\mathrm{UCF}$ & $\begin{array}{l}\bullet \quad \downarrow \text { Airway hyperreactivity and } \\
\text { Th2/Th17-mediated airway } \\
\text { inflammation }\end{array}$ & & [48] \\
\hline & $\begin{array}{l}\text { Human } \\
\text { AD-MSCs }\end{array}$ & mouse & Ovalbumin & IV & $37 \mu \mathrm{g}$ protein & $\mathrm{UCF}$ & $\begin{array}{l}\cdot \quad \downarrow \text { Lung elastance, collagen } \\
\text { deposition, lung and BALF eosinophils, } \\
\text { and BALF T lymphocytes } \\
\bullet \quad \uparrow \text { Treg cells in BALF and modulation } \\
\text { of lung cytokines }\end{array}$ & & [49] \\
\hline \multirow[t]{3}{*}{ Silicosis } & $\begin{array}{l}\text { Human } \\
\text { BM-MSCs }\end{array}$ & mouse & $\begin{array}{l}\text { Silica-induced } \\
\quad \text { fibrosis }\end{array}$ & IV & $10 \mu \mathrm{g}$ protein & ExoQuick & $\begin{array}{l}\bullet \quad \downarrow \text { Lung fibrosis, inflammatory cells } \\
\text { in airways and collagen deposition in } \\
\text { lung parenchymal }\end{array}$ & & [50] \\
\hline & $\begin{array}{c}\text { Mouse } \\
\text { AD-MSCs }\end{array}$ & mouse & $\begin{array}{l}\text { Silica-induced } \\
\quad \text { fibrosis }\end{array}$ & IT & $\begin{array}{l}\text { EVs released by } 1 \times 10^{6} \\
\text { MSCs over } 24 \mathrm{~h}\end{array}$ & $\mathrm{UCF}$ & $\begin{array}{l}-\downarrow \text { Lung collagen content, granuloma } \\
\text { size, and number of macrophages inside } \\
\text { granuloma and in the alveolar septa } \\
-\downarrow \text { Expression inflammatory cytokines } \\
\text { and lung static elastance }\end{array}$ & & [51] \\
\hline & $\begin{array}{l}\text { Human } \\
\text { BM-MSCs }\end{array}$ & mouse & $\begin{array}{l}\text { Silica-induced } \\
\quad \text { fibrosis }\end{array}$ & IV & $40 \mu \mathrm{g}$ protein & $\mathrm{UCF}$ & $\begin{array}{l}\text { - } \quad \downarrow \text { Lung nodules, WBC influx, and } \\
\text { levels of inflammatory and pro-fibrotic } \\
\text { genes and enhanced macrophage } \\
\text { energetics } \\
\text { - Inhibition of TLR signaling in } \\
\text { macrophages }\end{array}$ & $\begin{array}{l}\text { Effects partially modulated } \\
\text { EV transfer of mitochondria } \\
\text { and miRNAs }\end{array}$ & [52] \\
\hline
\end{tabular}




\subsection{Idiopathic Pulmonary Fibrosis}

Idiopathic Pulmonary Fibrosis (IPF) is a chronic and progressive fibrosing interstitial lung disease with pathophysiology characterized by fibroblast proliferation and extracellular matrix remodeling [53]. IPF has multiple genetic associations but no clearly defined cause and few effective treatments. Pirfenidone and nintedanib are the only currently United States Food and Drug Administration (FDA)-approved options for treatment, but they do not significantly ameliorate respiratory symptoms, improve the rate of acute exacerbations, or prevent the eventual decline of lung function [54-57]. Stem cell therapy has been used as a treatment for pulmonary fibrosis in pre-clinical animal models and in human patients with IPF. In animal models, these studies have demonstrated that adult stem cells can help to prevent the progression of pulmonary fibrosis in the bleomycin-induced pulmonary fibrosis model $[58,59]$. In human studies, MSC-based therapy has been shown to be safe and well-tolerated and improved quality-of-life parameters in phase 1 clinical trials [60-62]. As with other pulmonary diseases, there is now increasing interest in using the EVs released from mesenchymal stem cells for IPF therapies.

A study by Mansouri et al. demonstrated that intravenous human bone marrow MSC-derived EVs could prevent and reverse intratracheal bleomycin-induced pulmonary fibrosis in mice with resulting improvements in both pulmonary morphology and lung architecture and decreased collagen deposition [41]. They also showed the MSC-derived EVs were immunomodulatory and reduced monocyte-driven inflammation. Tan and colleagues demonstrated that intranasally-instilled human amnion epithelial-derived EVs, but not fibroblast-derived EVs, reduced lung inflammation and can both prevent or resolve bleomycin-induced lung injury depending on the timing of EV treatment after bleomycin injury [42]. The amnion epithelium-derived EVs also had a direct effect on immune cells, including increased macrophage phagocytosis, reduced neutrophil myeloperoxidase, and suppressed $\mathrm{T}$ cell proliferation. Shentu and colleagues used human bone marrow MSC-derived EVs to suppress the transforming growth factor beta 1 (TGF 31 )-stimulated myofibroblast differentiation of normal and IPF lung fibroblasts [63]. They found that MSC-derived EVs utilized a Thy1-integrin dependent pathway for cell-to-cell communication for uptake into fibroblasts and the delivery of EV cargo and resulting anti-fibrotic activity. The MSC-derived EVs contained several miRNAs, which target pro-fibrotic genes that are upregulated in IPF fibroblasts. In another study conducted by Shentu and colleagues, the IV injection of MSC-derived EVs into mice 14 days after bleomycin-induced pulmonary injury resulted in decreased pulmonary fibrosis. This model suggests a possible therapeutic effect of bone marrow MSC-derived EVs on established lung fibrosis by modulating the myofibroblastic phenotype [43].

\subsection{Pulmonary Arterial Hypertension}

Pulmonary Arterial Hypertension (PAH) refers to hemodynamic alterations of the pulmonary circulation in which the pulmonary artery pressures are $>25 \mathrm{~mm} \mathrm{Hg}$. PAH is a progressive disease characterized by the remodeling of the pulmonary arteries, increased pulmonary infiltrates, loss of vascular cross-sectional area, and elevated pulmonary vascular resistance leading to right heart failure and death $[64,65]$. A key pathological feature of PAH is vascular remodeling, which includes the accumulation of various cells, including pulmonary artery smooth muscle cells, endothelial cells, fibroblasts, myofibroblasts, and pericytes, in the pulmonary arterial wall [66]. In addition, there is loss of pre-capillary arteries and perivascular infiltration of inflammatory cells [66]. Despite significant research directed at therapies for $\mathrm{PAH}$, there are limited options available, and the current treatments do not improve the abnormal pulmonary vascular remodeling or inflammation seen in this disease. The goal in PAH is to find a therapy that would reverse the key features of PAH and result in the subsequent regeneration of normal pulmonary vessels. Thus, there is active research in exploring MSC-derived EVs as a possible PAH treatment.

To evaluate the effect of MSC-derived EVs on pulmonary vasculature, Lee and colleagues used a murine hypoxia-induced pulmonary hypertension murine model [44]. They demonstrated that IV treatment with MSC-derived EVs, but not fibroblast EVs, suppressed the influx of lung macrophages, 
the induction of multiple pro-inflammatory and proliferative mediators, and inhibited vascular remodeling, protecting against the development of right ventricular hypertrophy (RVH) and resultant PAH. The MSC-derived EV treatment decreased the signal transducer and activator of transcription 3 (STAT3)-mediated signaling induced by hypoxia, which is a key molecule involved in the response of pulmonary vasculature to hypoxia. They also found that MSC-derived EVs increased the lung expression levels of miR-204, an miRNA that is known to be suppressed in human pulmonary hypertension. Another group used a rat monocrotaline-induced PAH model and found that the IV injection of both MSCs and MSC-derived EVs resulted in a reduced mean pulmonary artery pressure and mean right ventricular pressure with a subsequent decrease in RVH [45]. This suggests that, in this system, the MSC-derived EVs are as effective as their cell of origin in preventing PAH. Using a similar monocrotaline-induced PAH model, Aliotta et al. demonstrated that bone marrow MSC-derived EVs could induce or prevent the development of PAH depending on the miRNA cargo [46]. In this study, IV treatment with EVs from monocrotaline injured mice induced RV hypertrophy and pulmonary vascular remodeling, whereas murine and human MSC-derived EVs reversed MCT-induced RV hypertrophy and pulmonary vascular remodeling. This group further separated out the MSC-derived EVs based on particle size and found that the MSC exosome fraction had a greater therapeutic effect compared to the microvesicle fraction. This difference was attributed, in part, to the MSC exosome fraction being enriched with anti-inflammatory and anti-proliferative miRNAs, including miRs-34a, -122, -124, and -127 , compared to the exosomes harvested from the plasma of healthy mice. Another report using the Sugen/hypoxia pulmonary hypertension rat model, demonstrated that MSC-derived EVs could prevent and reverse pulmonary hypertension with a subsequent reduction in $\mathrm{RVH}$ and pulmonary vascular remodeling [47].

\subsection{Silicosis}

Silicosis is an occupational disease caused by the inhalation of dust containing crystalline silica particles, resulting in lung inflammation and leading to a progressive and irreversible lung fibrosis $[67,68]$. Choi and colleagues were the first to show that human bone marrow MSC-derived EVs were able to reduce the influx of inflammatory cells and collagen deposition in a murine silicosis pulmonary fibrosis model [50]. Phinney et al. reported that human bone marrow MSC-derived EVs used arrestin domain-containing protein 1-mediated microvesicles to target depolarized mitochondria to the plasma membrane [52]. These vesicles are then taken up by macrophages and result in enhanced bioenergetics. Furthermore, they showed that miRNA contained in the EVs could inhibit macrophage activation by suppressing Toll-like receptor (TLR) signaling to desensitize the macrophage to the ingested mitochondria. They also demonstrated that the IV injection of MSC-derived EVs in the lung of silica-exposed mice reduced lung inflammation and the fibrotic response. Bandeira and colleagues demonstrated that intratracheal installation of adipose MSC-derived EVs in a silicosis mouse model led to a reduction in collagen deposition, granuloma size, and macrophage influx [51]. Furthermore, they showed a reduction in the expression of Interleukin $1 \beta$ and transforming growth factor $\beta$. Overall, the MSC-derived EVs reduced inflammation and fibrosis in a dose-dependent manner in this murine model of silicosis.

\subsection{Asthma}

Asthma is a chronic inflammatory lung disease characterized by intermittent airway obstruction, inflammation, increased mucus production, and bronchial hyperresponsiveness. There are multiple therapies on the market, but many patients continue to have poor disease control despite maximal treatment with current therapies. As a result, there is ongoing research to identify novel asthma therapies to both control and treat asthma exacerbations. For example, Cruz and colleagues successfully used MSC-derived EVs to alleviated allergic airway inflammation after the repeat mucosal exposures of Aspergillus hyphal extract in a murine model of severe asthma [48]. In another study, de Castro and colleagues used adipose-derived MSCs and MSC-derived EVs in an ovalbumin-induced allergic 
asthma murine model and found reduced inflammation and a reversal of tissue remodeling [49]. While the effects between MSCs and MSC-derived EVs were similar in this experiment, there were some differences in eosinophil counts and interleukin-4 (IL-4), interleukin-13 (IL-13), and eotaxin in lung tissue and $\mathrm{CD}^{+} \mathrm{CD}^{+} \mathrm{T}$ cells in BALF and in static lung elastance. This data suggests that MSCs and MSC-derived EVs have similarities and differences in their downstream immunomodulatory effects. In a different study, MSC-derived EVs were able to promote regulatory T cell proliferation by increasing the expression of IL-10 and TGF- $\beta 1$ in peripheral blood mononuclear cells from asthmatic patients [69].

\section{Therapeutic Development of EVs for Lung Injury and Disease}

MSC-derived EVs are now being considered as an effective and safer alternative to live MSC transplantation and have been shown to have therapeutic benefit in numerous pre-clinical models of pulmonary injury and disease. Nonetheless, the research is still in its infancy and there are still many unanswered questions that need to be addressed before MSC-derived EVs can become serious candidates as a clinical therapeutic.

There will need to be standardized protocols for the production, purification, characterization, and storage of EVs, as currently there are no universally accepted protocols. The techniques used for EV quantification include protein concentration, nanoparticle tracking analysis, tunable resistive pulse sensing, vesicle flow cytometry, surface plasma resonance, and electron microscopy. There are many recent reviews describing the predominant methods currently being used in the field [11,13,70-72]. The culture conditions and external stimuli of MSCs during EV production can alter the rate of EVs secreted and the EV composition, with resultant changes in the observed effects [17-19,73]. For example, MSCs pretreated with interleukin 1 beta (IL-1 $\beta$ ) had an increased ability to induce the polarization of macrophages towards an anti-inflammatory M2 phenotype. This effect was due to paracrine activity modulated via the upregulation and transfer of the exosomal miR-146 [18]. Another study found that EVs from MSCs pretreated with LPS also enhance the polarization of macrophages towards an anti-inflammatory M2 phenotype [19]. The mechanisms behind how these external factors alter the EV cargo and effects is unknown. Understanding how the EV contents are altered in response to stimuli and what downstream effects those alterations have will be important to both the basic mechanistic understanding of how EVs signal. This may allow for exploitation of this pathway to increase the production of EVs and enhance their function.

MSCs are harvested from a variety of donors, hence a better understanding of how donor characteristics may alter EV function will also need to be explored. There is much interest in personalizing medicine, and MSC-derived therapies are ideally suited for this approach, as autologous MSCs could be used to generate personalized EVs as a therapy. Thus, fully understanding the donor effects on EVs would become very important when considering using autologous EVs as therapy.

The treatment of lung diseases will require EV administration via IT instillation or IV injection. The optimal route of administering EVs and the bio-distribution of EVs based on the cellular origin of the EV and the route of administration will need to be clarified. Currently, there are no published reports of the bio-distribution of EVs after IT instillation. However, the intravenous injection of EVs into mice has been shown to initially localize primarily to the spleen and liver and then rapidly redistribute to the gastrointestinal tract and lungs, followed by renal and hepatic clearance [74,75]. There also needs to be a better understanding of dose-response studies with EVs to establish EV dosing concentration, half-life, and whether repeat dosing will be necessary to reach optimal plasma or tissue levels. As with many therapeutics, chronic dosing is necessary so the effectiveness over time and the potential for a possible drug tolerance to form will also need to be explored. Moreover, in order to scale-up EV production to meet the levels needed for clinical uses, there will need to be well-defined methods and protocols that maintain a homogenous EV consistency and purity. In addition, understanding the ideal EV storage conditions which maintain stability and efficacy will have to be developed. Thus, there are many biological and technical hurdles that have to be addressed in order for MSC-derived EVs to be developed as a therapeutic. 


\section{Conclusions}

In conclusion, we have summarized the current literature on the use of MSC-derived EVs as a treatment for acute and chronic lung disease. MSCs have shown promise for their regenerative and immune modulating effects but have been questioned as a therapeutic due to possible deleterious side effects. MSC-derived EVs are shown to be able to mediate many of the beneficial effects of MSCs, and it is postulated that they have fewer negative side-effects. Pre-clinical animal models have demonstrated that MSC-derived EV-based therapy may be a viable therapeutic option for the reversal or prevention of various lung diseases. This beneficial effect appears to be the result of the activation of the signaling pathways via the transfer of EV contents containing miRNA, RNA, and proteins; however, the molecular mechanisms of the different $\mathrm{EV}$ components is poorly understood. The current literature using MSC-derived EVs as a treatment for lung diseases in pre-clinical animal models use different methods of quantifying the dose of EVs, making direct comparison between the studies impossible. A consensus on the best method to define the EV dose needs to be determined so the therapeutic effectiveness of EVs can be compared across studies. In addition, there remains the challenge of scaling-up the production of EVs to a level that could be produced with clinical-grade quality and quantity. Thus, there are many questions and technical issues that need to be addressed before MSC-derived EVs can make the transition from animal models to humans. If these different challenges can be overcome, then MSC-derived EVs hold great promise as a potential therapeutic for numerous lung diseases.

Author Contributions: E.N.W. and J.S.H. conceived, planned and wrote the manuscript. All authors have read and agreed to the published version of the manuscript.

Funding: E.N.W. is supported by a grant from NIH/NHLBI (T32 HL007106).

Conflicts of Interest: The authors declare no conflict of interest. The funders had no role in the design of the study; in the collection, analyses, or interpretation of data; in the writing of the manuscript, or in the decision to publish the results.

\section{Abbreviations}

$\begin{array}{ll}\text { AD } & \text { Adipose tissue } \\ \text { ALI } & \text { Acute lung injury } \\ \text { Ang-1 } & \text { Angiopoietin-1 } \\ \text { ARDS } & \text { Acute respiratory distress syndrome } \\ \text { BM } & \text { Bone Marrow } \\ \text { BALF } & \text { Bronchoalveolar lavage fluid } \\ \text { BPD } & \text { Bronchopulmonary dysplasia } \\ \text { ESCRT } & \text { Endosomal sorting complexes required for transport } \\ \text { EV } & \text { Extracellular Vesicle } \\ \text { HGF } & \text { Hepatocyte Growth Factor } \\ \text { HIE } & \text { Hypoxic ischemic encephalopathy } \\ \text { IL } & \text { Interleukin } \\ \text { IN } & \text { Intranasal } \\ \text { IP } & \text { Intraperitoneal } \\ \text { IT } & \text { Intratracheal } \\ \text { IV } & \text { Intravenous } \\ \text { KGF } & \text { Keratinocyte growth factor } \\ \text { LPS } & \text { Lipopolysaccharide } \\ \text { miRNA } & \text { microRNA } \\ \text { MIP-2 } & \text { Macrophage inflammatory protein 2 } \\ \text { MDMs } & \text { Monocyte-derived macrophages } \\ \text { MSCs } & \text { Mesenchymal stem cells } \\ \text { MSC-derived EVs } & \text { Mesenchymal stem cell-derived extracellular vesicles } \\ \text { MVBs } & \text { Multivesicular bodies }\end{array}$




$\begin{array}{ll}\text { PAH } & \text { Pulmonary arterial hypertension } \\ \text { Thy } 1 & \text { Thymocyte differentiation antigen } 1 \\ \text { TGF } \beta 1 & \text { Transforming growth factor beta 1 } \\ \text { TSG-6 } & \text { Tumor necrosis factor alpha-stimulated gene-6 } \\ \text { UC } & \text { Umbilical cord } \\ \text { WBC } & \text { White blood cell }\end{array}$

\section{References}

1. Ntege, E.H.; Sunami, H.; Shimizu, Y. Advances in regenerative therapy: A review of the literature and future directions. Regen. Ther. 2020, 14, 136-153. [CrossRef]

2. Brignier, A.C.; Gewirtz, A.M. Embryonic and adult stem cell therapy. J. Allergy Clin. Immunol. 2010, 125, S336-S344. [CrossRef]

3. Burgess, J.K.; Heijink, I.H. Stem Cell-Based Therapy for Lung Disease; Springer: Cham, Switzerland, 2019.

4. $\quad$ Pittenger, M.F.; Discher, D.E.; Peault, B.M.; Phinney, D.G.; Hare, J.M.; Caplan, A.I. Mesenchymal stem cell perspective: Cell biology to clinical progress. NPJ Regen. Med. 2019, 4, 22. [CrossRef]

5. Cruz, F.F.; Rocco, P.R.M. The potential of mesenchymal stem cell therapy for chronic lung disease. Expert Rev. Respir. Med. 2020, 14, 31-39. [CrossRef]

6. Liu, A.; Zhang, X.; He, H.; Zhou, L.; Naito, Y.; Sugita, S.; Lee, J.W. Therapeutic potential of mesenchymal stem/stromal cell-derived secretome and vesicles for lung injury and disease. Expert Opin. Biol. Ther. 2020, 20, 125-140. [CrossRef]

7. Volarevic, V.; Markovic, B.S.; Gazdic, M.; Volarevic, A.; Jovicic, N.; Arsenijevic, N.; Armstrong, L.; Djonov, V.; Lako, M.; Stojkovic, M. Ethical and safety issues of stem cell-based therapy. Int. J. Med. Sci. 2018, 15, 36-45. [CrossRef]

8. Harrell, C.R.; Jankovic, M.G.; Fellabaum, C.; Volarevic, A.; Djonov, V.; Arsenijevic, A.; Volarevic, V. Molecular mechanisms responsible for anti-inflammatory and immunosuppressive effects of mesenchymal stem cell-derived factors. Adv. Exp. Med. Biol. 2019, 1084, 187-206. [CrossRef]

9. Seo, Y.; Kim, H.S.; Hong, I.S. Stem cell-derived extracellular vesicles as immunomodulatory therapeutics. Stem Cells Int. 2019, 2019, 5126156. [CrossRef]

10. Zhu, X.; Badawi, M.; Pomeroy, S.; Sutaria, D.S.; Xie, Z.; Baek, A.; Jiang, J.; Elgamal, O.A.; Mo, X.; Perle, K.; et al. Comprehensive toxicity and immunogenicity studies reveal minimal effects in mice following sustained dosing of extracellular vesicles derived from HEK293T cells. J. Extracell. Vesicles 2017, 6, 1324730. [CrossRef]

11. Witwer, K.W.; Buzas, E.I.; Bemis, L.T.; Bora, A.; Lasser, C.; Lotvall, J.; Nolte-'t Hoen, E.N.; Piper, M.G.; Sivaraman, S.; Skog, J.; et al. Standardization of sample collection, isolation and analysis methods in extracellular vesicle research. J. Extracell. Vesicles 2013, 2. [CrossRef]

12. van Niel, G.; D'Angelo, G.; Raposo, G. Shedding light on the cell biology of extracellular vesicles. Nat. Rev. Mol. Cell Biol. 2018, 19, 213-228. [CrossRef]

13. Thery, C.; Witwer, K.W.; Aikawa, E.; Alcaraz, M.J.; Anderson, J.D.; Andriantsitohaina, R.; Antoniou, A.; Arab, T.; Archer, F.; Atkin-Smith, G.K.; et al. Minimal information for studies of extracellular vesicles 2018 (MISEV2018): A position statement of the International Society for Extracellular Vesicles and update of the MISEV2014 guidelines. J. Extracell. Vesicles 2018, 7, 1535750. [CrossRef]

14. Cocucci, E.; Meldolesi, J. Ectosomes and exosomes: Shedding the confusion between extracellular vesicles. Trends Cell Biol. 2015, 25, 364-372. [CrossRef]

15. Abels, E.R.; Breakefield, X.O. Introduction to extracellular vesicles: Biogenesis, RNA cargo selection, content, release, and uptake. Cell. Mol. Neurobiol. 2016, 36, 301-312. [CrossRef]

16. Alenquer, M.; Amorim, M.J. Exosome biogenesis, regulation, and function in viral infection. Viruses 2015, 7, 5066-5083. [CrossRef] [PubMed]

17. Madrigal, M.; Rao, K.S.; Riordan, N.H. A review of therapeutic effects of mesenchymal stem cell secretions and induction of secretory modification by different culture methods. J. Transl. Med. 2014, 12, 260. [CrossRef] [PubMed]

18. Song, Y.; Dou, H.; Li, X.; Zhao, X.; Li, Y.; Liu, D.; Ji, J.; Liu, F.; Ding, L.; Ni, Y.; et al. Exosomal miR-146a contributes to the enhanced therapeutic efficacy of interleukin-1beta-primed mesenchymal stem cells against sepsis. Stem Cells 2017, 35, 1208-1221. [CrossRef] [PubMed] 
19. Ti, D.; Hao, H.; Tong, C.; Liu, J.; Dong, L.; Zheng, J.; Zhao, Y.; Liu, H.; Fu, X.; Han, W. LPS-preconditioned mesenchymal stromal cells modify macrophage polarization for resolution of chronic inflammation via exosome-shuttled let-7b. J. Transl. Med. 2015, 13, 308. [CrossRef]

20. Mathieu, M.; Martin-Jaular, L.; Lavieu, G.; Thery, C. Specificities of secretion and uptake of exosomes and other extracellular vesicles for cell-to-cell communication. Nat. Cell Biol. 2019, 21, 9-17. [CrossRef]

21. Tkach, M.; Thery, C. Communication by extracellular vesicles: Where we are and where we need to go. Cell 2016, 164, 1226-1232. [CrossRef]

22. Fujita, Y.; Kadota, T.; Araya, J.; Ochiya, T.; Kuwano, K. Clinical application of mesenchymal stem cell-derived extracellular vesicle-based therapeutics for inflammatory lung diseases. J. Clin. Med. 2018, 7, 355. [CrossRef] [PubMed]

23. Thompson, B.T.; Chambers, R.C.; Liu, K.D. Acute respiratory distress syndrome. N. Engl. J. Med. 2017, 377, 562-572. [CrossRef] [PubMed]

24. Sweeney, R.M.; McAuley, D.F. Acute respiratory distress syndrome. Lancet 2016, 388, 2416-2430. [CrossRef]

25. Confalonieri, M.; Salton, F.; Fabiano, F. Acute respiratory distress syndrome. Eur. Respir. Rev. 2017, 26. [CrossRef] [PubMed]

26. Fan, E.; Brodie, D.; Slutsky, A.S. Acute respiratory distress syndrome: Advances in diagnosis and treatment. JAMA 2018, 319, 698-710. [CrossRef] [PubMed]

27. Khatri, M.; Richardson, L.A.; Meulia, T. Mesenchymal stem cell-derived extracellular vesicles attenuate influenza virus-induced acute lung injury in a pig model. Stem Cell Res. Ther. 2018, 9, 17. [CrossRef] [PubMed]

28. Monsel, A.; Zhu, Y.G.; Gennai, S.; Hao, Q.; Hu, S.; Rouby, J.J.; Rosenzwajg, M.; Matthay, M.A.; Lee, J.W. Therapeutic effects of human mesenchymal stem cell-derived microvesicles in severe pneumonia in mice. Am. J. Respir. Crit. Care Med. 2015, 192, 324-336. [CrossRef]

29. Morrison, T.J.; Jackson, M.V.; Cunningham, E.K.; Kissenpfennig, A.; McAuley, D.F.; O’Kane, C.M.; Krasnodembskaya, A.D. Mesenchymal stromal cells modulate macrophages in clinically relevant lung injury models by extracellular vesicle mitochondrial transfer. Am. J. Respir. Crit. Care Med. 2017, 196, 1275-1286. [CrossRef]

30. Zhu, Y.G.; Feng, X.M.; Abbott, J.; Fang, X.H.; Hao, Q.; Monsel, A.; Qu, J.M.; Matthay, M.A.; Lee, J.W. Human mesenchymal stem cell microvesicles for treatment of Escherichia coli endotoxin-induced acute lung injury in mice. Stem Cells 2014, 32, 116-125. [CrossRef]

31. Tang, X.D.; Shi, L.; Monsel, A.; Li, X.Y.; Zhu, H.L.; Zhu, Y.G.; Qu, J.M. Mesenchymal stem cell microvesicles attenuate acute lung injury in mice partly mediated by ang-1 mRNA. Stem Cells 2017, 35, 1849-1859. [CrossRef]

32. Hu, S.; Park, J.; Liu, A.; Lee, J.; Zhang, X.; Hao, Q.; Lee, J.W. Mesenchymal stem cell microvesicles restore protein permeability across primary cultures of injured human lung microvascular endothelial cells. Stem Cells Transl. Med. 2018, 7, 615-624. [CrossRef] [PubMed]

33. Wang, H.; Zheng, R.; Chen, Q.; Shao, J.; Yu, J.; Hu, S. Mesenchymal stem cells microvesicles stabilize endothelial barrier function partly mediated by hepatocyte growth factor (HGF). Stem Cell Res. Ther. 2017, 8 , 211. [CrossRef] [PubMed]

34. Gennai, S.; Monsel, A.; Hao, Q.; Park, J.; Matthay, M.A.; Lee, J.W. Microvesicles derived from human mesenchymal stem cells restore alveolar fluid clearance in human lungs rejected for transplantation. Am. J. Transplant. 2015, 15, 2404-2412. [CrossRef]

35. Namba, F. Mesenchymal stem cells for the prevention of bronchopulmonary dysplasia. Pediatr. Int. 2019, 61, 945-950. [CrossRef] [PubMed]

36. Pierro, M.; Thebaud, B.; Soll, R. Mesenchymal stem cells for the prevention and treatment of bronchopulmonary dysplasia in preterm infants. Cochrane Database Syst. Rev. 2017, 11, CD011932. [CrossRef] [PubMed]

37. Simones, A.A.; Beisang, D.J.; Panoskaltsis-Mortari, A.; Roberts, K.D. Mesenchymal stem cells in the pathogenesis and treatment of bronchopulmonary dysplasia: A clinical review. Pediatr. Res. 2018, 83, 308-317. [CrossRef] 
38. Willis, G.R.; Fernandez-Gonzalez, A.; Anastas, J.; Vitali, S.H.; Liu, X.; Ericsson, M.; Kwong, A.; Mitsialis, S.A.; Kourembanas, S. Mesenchymal stromal cell exosomes ameliorate experimental bronchopulmonary dysplasia and restore lung function through macrophage immunomodulation. Am. J. Respir. Crit. Care Med. 2018, 197, 104-116. [CrossRef]

39. Chaubey, S.; Thueson, S.; Ponnalagu, D.; Alam, M.A.; Gheorghe, C.P.; Aghai, Z.; Singh, H.; Bhandari, V. Early gestational mesenchymal stem cell secretome attenuates experimental bronchopulmonary dysplasia in part via exosome-associated factor TSG-6. Stem Cell Res. Ther. 2018, 9, 173. [CrossRef]

40. Porzionato, A.; Zaramella, P.; Dedja, A.; Guidolin, D.; Van Wemmel, K.; Macchi, V.; Jurga, M.; Perilongo, G.; De Caro, R.; Baraldi, E.; et al. Intratracheal administration of clinical-grade mesenchymal stem cell-derived extracellular vesicles reduces lung injury in a rat model of bronchopulmonary dysplasia. Am. J. Physiol. Lung Cell. Mol. Physiol. 2019, 316, L6-L19. [CrossRef]

41. Mansouri, N.; Willis, G.R.; Fernandez-Gonzalez, A.; Reis, M.; Nassiri, S.; Mitsialis, S.A.; Kourembanas, S. Mesenchymal stromal cell exosomes prevent and revert experimental pulmonary fibrosis through modulation of monocyte phenotypes. JCI Insight 2019, 4. [CrossRef]

42. Tan, J.L.; Lau, S.N.; Leaw, B.; Nguyen, H.P.T.; Salamonsen, L.A.; Saad, M.I.; Chan, S.T.; Zhu, D.; Krause, M.; Kim, C.; et al. Amnion epithelial cell-derived exosomes restrict lung injury and enhance endogenous lung repair. Stem Cells Transl. Med. 2018, 7, 180-196. [CrossRef] [PubMed]

43. Shentu, T.P.; Wong, S.; Espinoza, C.; Cernelc-Kohan, M.; Hagood, J. Extracellular vesicles isolated from human mesenchymal stem cells promote resolution of pulmonary fibrosis. FASEB J. 2016, 30, 160-2. [CrossRef]

44. Lee, C.; Mitsialis, S.A.; Aslam, M.; Vitali, S.H.; Vergadi, E.; Konstantinou, G.; Sdrimas, K.; Fernandez-Gonzalez, A.; Kourembanas, S. Exosomes mediate the cytoprotective action of mesenchymal stromal cells on hypoxia-induced pulmonary hypertension. Circulation 2012, 126, 2601-2611. [CrossRef] [PubMed]

45. Chen, J.Y.; An, R.; Liu, Z.J.; Wang, J.J.; Chen, S.Z.; Hong, M.M.; Liu, J.H.; Xiao, M.Y.; Chen, Y.F. Therapeutic effects of mesenchymal stem cell-derived microvesicles on pulmonary arterial hypertension in rats. Acta Pharmacol. Sin. 2014, 35, 1121-1128. [CrossRef] [PubMed]

46. Aliotta, J.M.; Pereira, M.; Wen, S.; Dooner, M.S.; Del Tatto, M.; Papa, E.; Goldberg, L.R.; Baird, G.L.; Ventetuolo, C.E.; Quesenberry, P.J.; et al. Exosomes induce and reverse monocrotaline-induced pulmonary hypertension in mice. Cardiovasc. Res. 2016, 110, 319-330. [CrossRef] [PubMed]

47. Klinger, J.R.; Pereira, M.; Del Tatto, M.; Brodsky, A.S.; Wu, K.Q.; Dooner, M.S.; Borgovan, T.; Wen, S.; Goldberg, L.R.; Aliotta, J.M.; et al. Mesenchymal stem cell extracellular vesicles reverse sugen/hypoxia pulmonary hypertension in rats. Am. J. Respir. Cell. Mol. Biol. 2019. [CrossRef] [PubMed]

48. Cruz, F.F.; Borg, Z.D.; Goodwin, M.; Sokocevic, D.; Wagner, D.E.; Coffey, A.; Antunes, M.; Robinson, K.L.; Mitsialis, S.A.; Kourembanas, S.; et al. Systemic administration of human bone marrow-derived mesenchymal stromal cell extracellular vesicles ameliorates aspergillus hyphal extract-induced allergic airway inflammation in immunocompetent mice. Stem Cells Transl. Med. 2015, 4, 1302-1316. [CrossRef]

49. de Castro, L.L.; Xisto, D.G.; Kitoko, J.Z.; Cruz, F.F.; Olsen, P.C.; Redondo, P.A.G.; Ferreira, T.P.T.; Weiss, D.J.; Martins, M.A.; Morales, M.M.; et al. Human adipose tissue mesenchymal stromal cells and their extracellular vesicles act differentially on lung mechanics and inflammation in experimental allergic asthma. Stem Cell Res. Ther. 2017, 8, 151. [CrossRef]

50. Choi, M.; Ban, T.; Rhim, T. Therapeutic use of stem cell transplantation for cell replacement or cytoprotective effect of microvesicle released from mesenchymal stem cell. Mol. Cells 2014, 37, 133-139. [CrossRef]

51. Bandeira, E.; Oliveira, H.; Silva, J.D.; Menna-Barreto, R.F.S.; Takyia, C.M.; Suk, J.S.; Witwer, K.W.; Paulaitis, M.E.; Hanes, J.; Rocco, P.R.M.; et al. Therapeutic effects of adipose-tissue-derived mesenchymal stromal cells and their extracellular vesicles in experimental silicosis. Respir. Res. 2018, 19, 104. [CrossRef]

52. Phinney, D.G.; Di Giuseppe, M.; Njah, J.; Sala, E.; Shiva, S.; St Croix, C.M.; Stolz, D.B.; Watkins, S.C.; Di, Y.P.; Leikauf, G.D.; et al. Mesenchymal stem cells use extracellular vesicles to outsource mitophagy and shuttle microRNAs. Nat. Commun. 2015, 6, 8472. [CrossRef] [PubMed]

53. Raghu, G.; Collard, H.R.; Egan, J.J.; Martinez, F.J.; Behr, J.; Brown, K.K.; Colby, T.V.; Cordier, J.F.; Flaherty, K.R.; Lasky, J.A.; et al. An official ATS/ERS/JRS/ALAT statement: Idiopathic pulmonary fibrosis: Evidence-based guidelines for diagnosis and management. Am. J. Respir. Crit. Care Med. 2011, 183, 788-824. [CrossRef] [PubMed] 
54. Staitieh, B.S.; Renzoni, E.A.; Veeraraghavan, S. Pharmacologic therapies for idiopathic pulmonary fibrosis, past and future. Ann. Med. 2015, 47, 100-105. [CrossRef] [PubMed]

55. Raghu, G. Pharmacotherapy for idiopathic pulmonary fibrosis: Current landscape and future potential. Eur. Respir. Rev. 2017, 26. [CrossRef] [PubMed]

56. Richeldi, L.; du Bois, R.M.; Raghu, G.; Azuma, A.; Brown, K.K.; Costabel, U.; Cottin, V.; Flaherty, K.R.; Hansell, D.M.; Inoue, Y.; et al. Efficacy and safety of nintedanib in idiopathic pulmonary fibrosis. N. Engl. J. Med. 2014, 370, 2071-2082. [CrossRef] [PubMed]

57. King, T.E., Jr.; Bradford, W.Z.; Castro-Bernardini, S.; Fagan, E.A.; Glaspole, I.; Glassberg, M.K.; Gorina, E.; Hopkins, P.M.; Kardatzke, D.; Lancaster, L.; et al. A phase 3 trial of pirfenidone in patients with idiopathic pulmonary fibrosis. N. Engl. J. Med. 2014, 370, 2083-2092. [CrossRef]

58. Banerjee, E.R.; Laflamme, M.A.; Papayannopoulou, T.; Kahn, M.; Murry, C.E.; Henderson, W.R., Jr. Human embryonic stem cells differentiated to lung lineage-specific cells ameliorate pulmonary fibrosis in a xenograft transplant mouse model. PLoS ONE 2012, 7, e33165. [CrossRef]

59. Lee, S.H.; Jang, A.S.; Kim, Y.E.; Cha, J.Y.; Kim, T.H.; Jung, S.; Park, S.K.; Lee, Y.K.; Won, J.H.; Kim, Y.H.; et al. Modulation of cytokine and nitric oxide by mesenchymal stem cell transfer in lung injury/fibrosis. Respir. Res. 2010, 11, 16. [CrossRef]

60. Glassberg, M.K.; Minkiewicz, J.; Toonkel, R.L.; Simonet, E.S.; Rubio, G.A.; DiFede, D.; Shafazand, S.; Khan, A.; Pujol, M.V.; LaRussa, V.F.; et al. Allogeneic human mesenchymal stem cells in patients with idiopathic pulmonary fibrosis via intravenous delivery (AETHER): A phase I safety clinical trial. Chest 2017, 151, 971-981. [CrossRef]

61. Tzouvelekis, A.; Paspaliaris, V.; Koliakos, G.; Ntolios, P.; Bouros, E.; Oikonomou, A.; Zissimopoulos, A.; Boussios, N.; Dardzinski, B.; Gritzalis, D.; et al. A prospective, non-randomized, no placebo-controlled, phase $\mathrm{Ib}$ clinical trial to study the safety of the adipose derived stromal cells-stromal vascular fraction in idiopathic pulmonary fibrosis. J. Transl. Med. 2013, 11, 171. [CrossRef]

62. Ntolios, P.; Manoloudi, E.; Tzouvelekis, A.; Bouros, E.; Steiropoulos, P.; Anevlavis, S.; Bouros, D.; Froudarakis, M.E. Longitudinal outcomes of patients enrolled in a phase Ib clinical trial of the adipose-derived stromal cells-stromal vascular fraction in idiopathic pulmonary fibrosis. Clin. Respir. J. 2018, 12, 2084-2089. [CrossRef] [PubMed]

63. Shentu, T.P.; Huang, T.S.; Cernelc-Kohan, M.; Chan, J.; Wong, S.S.; Espinoza, C.R.; Tan, C.; Gramaglia, I.; van der Heyde, H.; Chien, S.; et al. Thy-1 dependent uptake of mesenchymal stem cell-derived extracellular vesicles blocks myofibroblastic differentiation. Sci. Rep. 2017, 7, 18052. [CrossRef] [PubMed]

64. Guazzi, M.; Naeije, R. Pulmonary hypertension in heart failure: Pathophysiology, pathobiology, and emerging clinical perspectives. J. Am. Coll. Cardiol. 2017, 69, 1718-1734. [CrossRef] [PubMed]

65. Galie, N.; Humbert, M.; Vachiery, J.L.; Gibbs, S.; Lang, I.; Torbicki, A.; Simonneau, G.; Peacock, A.; Vonk Noordegraaf, A.; Beghetti, M.; et al. 2015 ESC/ERS guidelines for the diagnosis and treatment of pulmonary hypertension. Rev. Esp. Cardiol. (Engl. Ed.) 2016, 69, 177. [CrossRef]

66. Humbert, M.; Guignabert, C.; Bonnet, S.; Dorfmuller, P.; Klinger, J.R.; Nicolls, M.R.; Olschewski, A.J.; Pullamsetti, S.S.; Schermuly, R.T.; Stenmark, K.R.; et al. Pathology and pathobiology of pulmonary hypertension: State of the art and research perspectives. Eur. Respir. J. 2019, 53. [CrossRef]

67. Hoy, R.F.; Chambers, D.C. Silica-related diseases in the modern world. Allergy 2020. [CrossRef]

68. Sato, T.; Shimosato, T.; Klinman, D.M. Silicosis and lung cancer: Current perspectives. Lung Cancer (Auckl.) 2018, 9, 91-101. [CrossRef]

69. Du, Y.M.; Zhuansun, Y.X.; Chen, R.; Lin, L.; Lin, Y.; Li, J.G. Mesenchymal stem cell exosomes promote immunosuppression of regulatory T cells in asthma. Exp. Cell Res. 2018, 363, 114-120. [CrossRef]

70. Xu, R.; Greening, D.W.; Zhu, H.J.; Takahashi, N.; Simpson, R.J. Extracellular vesicle isolation and characterization: Toward clinical application. J. Clin. Investig. 2016, 126, 1152-1162. [CrossRef]

71. Tschuschke, M.; Kocherova, I.; Bryja, A.; Mozdziak, P.; Angelova Volponi, A.; Janowicz, K.; Sibiak, R.; Piotrowska-Kempisty, H.; Izycki, D.; Bukowska, D.; et al. Inclusion biogenesis, methods of isolation and clinical application of human cellular exosomes. J. Clin. Med. 2020, 9, 436. [CrossRef]

72. van der Pol, E.; Boing, A.N.; Gool, E.L.; Nieuwland, R. Recent developments in the nomenclature, presence, isolation, detection and clinical impact of extracellular vesicles. J. Thromb. Haemost. 2016, 14, 48-56. [CrossRef] [PubMed] 
73. Burnouf, T.; Agrahari, V.; Agrahari, V. Extracellular vesicles as nanomedicine: Hopes and hurdles in clinical translation. Int. J. Nanomed. 2019, 14, 8847-8859. [CrossRef] [PubMed]

74. Lai, C.P.; Mardini, O.; Ericsson, M.; Prabhakar, S.; Maguire, C.; Chen, J.W.; Tannous, B.A.; Breakefield, X.O. Dynamic biodistribution of extracellular vesicles in vivo using a multimodal imaging reporter. ACS Nano 2014, 8, 483-494. [CrossRef] [PubMed]

75. Wiklander, O.P.; Nordin, J.Z.; O’Loughlin, A.; Gustafsson, Y.; Corso, G.; Mager, I.; Vader, P.; Lee, Y.; Sork, H.; Seow, Y.; et al. Extracellular vesicle in vivo biodistribution is determined by cell source, route of administration and targeting. J. Extracell. Vesicles 2015, 4, 26316. [CrossRef]

(C) 2020 by the authors. Licensee MDPI, Basel, Switzerland. This article is an open access article distributed under the terms and conditions of the Creative Commons Attribution (CC BY) license (http://creativecommons.org/licenses/by/4.0/). 